\title{
IMPROVING STUDENTS' WRITING SKILL USING NUMBERED HEADS TOGETHER TECHNIQUE WITH PICTURE SERIES
}

\author{
Gagas Rambu Pamungkas, Suparno, Ellisa Indriyani Putri Handayani \\ English Education Department \\ Teacher Training and Education Faculty \\ Sebelas Maret University of Surakarta
}

Email: gagasrp93@gmail.com

\begin{abstract}
This research was conducted to improve the students' writing skill at the tenth grade of SMAN 1 Sukoharjo in the academic year 2015/2016. The method used in this research is a classroom action research which the in two cycles. The research data were collected using the qualitative and quantitative technique. The qualitative technique consisted of observation, field notes, interview, document analysis, and documentation. Meanwhile, the quantitative technique used tests. The qualitative data the through data collection, data reduction, data display, and drawing a conclusion. The quantitative data were analyzed by comparing the mean score of the pre-test and the post-test. The findings of the research showed that (1) NHT technique with picture series could be implemented to teach writing skill; (2) there were some improvements in the class situation of writing class. As seen in the students' responses toward teacher's explanation during teaching learning activity, students enjoy the way teacher delivers materials with picture series as the teaching media, and students tend to be active; (3) the students' writing score was improved from 60.7 in pretest to 71.9 in the first post-test and to 79.5 in the second post-test.
\end{abstract}

Keywords: writing skill, Numbered Heads Together (NHT) technique, picture series media, action research

\section{INTRODUCTION}

Writing is one of the four language skills in teaching English. It has occupied a place in most English language courses. Most English learners said that writing is a difficult skill because in writing the writer must be able to organize the idea, to construct sentences, to use punctuation and spelling well. This statement is supported by Westwood (2008: 56), who says that written language is belongs to the most difficult of all skills to acquire because its development involves the effective coordination of many differences cognitive, linguistics and psycho-motor process.

Scott and Yterberg (1990:68) state that writing is not an easy skill. Writing has certain characteristics which seem to make it difficult for pupils, especially for younger pupils. However, they also believe that writing is a useful, essential, integral, and enjoyable part of a foreign language lesson. It will always be valuable, especially when seeing the work in print, and its satisfaction in having written something which someone.

Writing is not only about anything in a paper as we like, but in this context, it has to use the right steps, rules and it involves many aspects. Brown (2001: 336) claims that writing is a thinking process. He also states that writing can be planned and given with an unlimited number of revisions before its release. When someone wants to 
write something, actually there are some stages or process to get a good writing.

In Indonesia, writing activity has been done in academic field which has beneficially improved students' writing skill. Especially in the tenth grade of Senior High School as the object of this research, based on Competency Standard - Standar Kompetensi (SK) and Basic Competency Kompetensi Dasar (KD) of Curriculum 2013, the students are expected to be able to express meaningful ideas in term of functional text and simple short essay in written form.

However, the fact in the classroom showed that the students had problems with their ability in writing descriptive text and also they got difficulties generating or organizing their ideas in the written form. Based on pre-research data, the researcher found that most of the students in the tenth grade of SMA N 1 Sukoharjo had difficulties in making a text genre type of descriptive text. Most students had low ability in writing skill. The data showed that when the teacher asked them to make a descriptive text they felt confused about where they had to start and how to develop their idea. They were still confused in organizing the writing descriptive text or the generic structures. The main problems that happen in this class are they have low ability in grammar and they were still confused whether should use the present tense of past tense. In addition, their choice of words sometimes is not correct and inappropriate, lack of vocabulary makes the spelling wrong, and they do not realize it.

The other problem found by the researcher was the teaching technique. Based on the pre-research observation, the teaching technique in writing class used by the teacher was monotonous. During the teaching-learning process, the teacher just delivered the material from the students' worksheet - Lembar Kerja Siswa (LKS) or it could be said as conventional teaching. This condition made students felt bored and not interested in writing class. Moreover, there was no teaching media as a tool to help the teacher deliver the material.

In teaching writing, there is a teachers' purpose to achieve the goal. It makes their students able to make a wellwritten text. So, teachers need a technique of teaching writing which can be implemented in their classroom. the It makes them more concern to achieve their classroom work and also improve the quality and effectiveness of teaching and learning in class.

Therefore, the researcher thought that the most important thing to improve students' skill at the tenth grade of SMA N 1 Sukoharjo is there are teaching technique and media which are appropriate to implement in writing class. In this action research, the researcher chose one of teaching techniques entitled Numbered Heads Together (NHT). NHT is one of cooperative learning technique which focuses on the students' teamwork. It can be used to teach every subject and every level.

This statement is supported by Lie (2004: 59), Numbered Heads Together (NHT) is one of cooperative learning types that give the students chances to share their ideas and discuss the best answer when they are given some questions by the teacher. Then, she tells that NHT encourages students to improve their enthusiasm while they are working in groups, moreover NHT is characterized by heterogeneous groups working together to achieve a common goal. Based on this theory, the researcher thought that NHT would be an effective teaching technique if it could be implemented in writing class.

Beside teaching technique that should use by teachers when teaching in the class, the teacher also should provide 
teaching media. Every teaching and learning process needs a teaching media to deliver the teaching material to the students. According to Anitah (2008: 1), teaching media is something which is used to deliver a learning message from sender to the receiver. In this case sender is the teacher and receiver is the students in the classroom.

There are many teaching media that can be used by the teacher. However, in this research, the researcher used picture series as the teaching media. Shores (1996: 188) says, "Pictures are the likeness of a person, place, thing or idea on a flat object, produced by means of drawing, painting, or photography." From all kinds of media, a picture may be the easy one to be got. Since pictures can be got from any sources, it is not difficult for the teacher to find it. They can copy from their books or find it on the internet. Callahan, et al. (1992: 479) suggests the teachers use pictures effectively because the media are very useful for the teaching. Many interpretations can be made in a picture. It can be an excellent tool and can illustrate what teachers wish to teach. A picture not only provides the students with the basic material for their composition but also stimulates their imaginative powers.

In this classroom action research, the researcher tried to combine Numbered Heads Together (NHT) technique with picture series as the teaching media to teach writing. Based on the teacher's interview in the pre-research, the researcher found that the English teacher had never used NHT technique to teach writing before. So, the purposes of this research are to identify how to implement Numbered Heads Together (NHT) technique with picture series as the teaching media in teaching writing, then the researcher also want to know the classroom situation and students' response after implementing Numbered Heads Together (NHT) technique with Picture Series in writing class, and the last objective is to know whether or not Numbered Heads Together (NHT) technique with picture series can improve the students' writing skill.

\section{RESEARCH METHOD}

In this study, the research method used by the researcher is classroom action research (CAR) that conducted at the tenthgrade students of SMA N 1 Sukoharjo in the academic year 2015/2016.

The use of Classroom Action Research as the research method is believed can help the teacher to find the appropriate teaching technique to solve the problems found in the classroom. According to Ebbut (1985) in Hopkins (1993: 45), action research is about the systematic study of attempts to improve educational practice by groups of participants and by means of their own practical actions and by means of own reflection upon the effects of that action.

Classroom Action Research can be done in varieties way. First, the researcher can take a role as the designer of the teaching method, whereas the teacher as the implementer; Second, an action research can be done collaboratively. Burns (1999: 34) explains that action research may be carried out through different combinations of people working together: by group of teachers working with university researchers; by teacher-researchers pairs or group working together; by teachers working in partnership with administrators, students, parents or community members.

Based on those theories, it could be said that the main characteristic of action research is participation and collaboration between the researcher, teacher and the member of that target community to solve the problems in the classroom. In this case, the target community or the subject of the research was class X-IIS 1 in SMA N 1 
Sukoharjo. The researcher cooperated with an English teacher of the X grade in SMA N 1 Sukoharjo. The classroom action research was carried out by the researcher collaboratively with the teacher by implementing Numbered Heads Together (NHT) technique with picture series as the teaching media.

The model of action research that was used in this research is action research developed by Kemmis and McTaggart in Burns (1999: 33). The main process consists of planning, action, observation, and reflection. Furthermore, in this research, the researcher uses the qualitative and quantitative techniques of collecting the data. The qualitative data was collected through observation, interviews, field notes, and document, while in the quantitative data used tests. The qualitative data were analyzed through data collection, data reduction, data display, and drawing conclusion. The quantitative data were analyzed by comparing the mean score of the pre-test and the post-test.

\section{RESEARCH FINDINGS AND DISCUSSION}

The research was conducted with the collaboration of English teacher on class X IIS 1 of SMA Negeri 1 Sukoharjo in the academic year 2015/2016. In this research, the researcher became the practitioner who implemented the action. Meanwhile, the English teacher became the collaborator and facilitator. The teacher was helped by an observer to observe the teaching and learning process until the end of the research.

Before the researcher implemented the action, he conducted a preliminary research in order to find out the problem faced by the students in learning English, especially in writing class. Based on the preresearch data, the researcher found that there were students' problems in writing skill and also the classroom situation was not effective. The result of pre-test score also shown that the students' writing score was still low, it was proved by the students' mean score of the pre-test was only 60.7. It was far below the minimum achievement criteria (KKM) which are 75. The researcher conducted preliminary research on August 22, 2015, and August 29, 2015. The detail of pre-research findings can be seen in table 1 .

Table 1 Pre-Research Findings

\begin{tabular}{|c|c|}
\hline Problem Indicators & Description \\
\hline A. Pre-Test Score & $\begin{array}{l}\text { - The students' highest score was } 77.5 \text {, the lowest was } 50 \text {, and the mean score } \\
\text { was } 60.7 \text {, }\end{array}$ \\
\hline B. Writing Aspects & $\begin{array}{l}\text { - Students difficulty in developing the content. } \\
\text { - The students were confused how to start. They often made mistake in stating } \\
\text { the main idea for their writing. } \\
\text { - The students had limited vocabularies which made them difficult to select and } \\
\text { use the appropriate words for their writing. } \\
\text { - The students made many grammatical mistakes, including incorrect tenses, } \\
\text { they often forgot to keep the consistency to use present tense in their writing. } \\
\text { - The students still used the wrong punctuation, like when it should use a } \\
\text { comma or full stop to make the sentences, not in ambiguity. }\end{array}$ \\
\hline
\end{tabular}

C. Class Situation

- Students did not pay attention to the teacher, almost all of them did not respect the researcher's explanation. 
- Many students always asked inappropriate questions to the teacher about the task, sometimes they were just quiet if they found any difficulties.

- Many students did non-academic activities rather than focused the lesson. non-academic

- The students were not willing to speak English in the classroom.

Based on the findings of the preliminary research, the students' writing skill should be improved by using teaching technique and media which can overcome the problems. In this study, the researcher used Numbered Heads Together (NHT) technique with picture series as the teaching media to teach writing.
It was very interesting to implement this teaching technique because based on the teacher's statement; he said that he had never implemented NHT technique before. The research was carried out in two cycles. There were three meetings in cycle I. The summary of the cycle I activities are described in table 2

Table 2 Summary of Cycle I Activities

\begin{tabular}{|c|c|c|}
\hline Cycle & $\begin{array}{l}\text { Meeting / } \\
\text { Date }\end{array}$ & Activities \\
\hline Cycle 1 & $\begin{array}{l}1^{\text {st }} \text { Meeting } \\
\text { November } 9^{\text {th }}, 2015\end{array}$ & $\begin{array}{l}\text { - The researcher explained about Descriptive Text which contained the } \\
\text { definition, purpose, generic structure, and language features. } \\
\text { - The researcher showed picture series about tourist resorts and asked } \\
\text { students to describe them in simple sentences. }\end{array}$ \\
\hline & $\begin{array}{l}2^{\text {nd }} \text { Meeting } \\
\text { November } 14^{\text {th }}, 2015\end{array}$ & $\begin{array}{l}\text { - The researcher showed some students' work on the LCD, and then he } \\
\text { asked the students to analyze it. } \\
\text { - The researcher started to use Number Heads Together (NHT) } \\
\text { technique and then asked the students to make groups work. } \\
\text { - The students made descriptive text using (NHT) technique with } \\
\text { picture series as the media. }\end{array}$ \\
\hline & $\begin{array}{l}3^{\text {rd }} \text { Meeting } \\
\text { November } 16^{\text {th }}, 2015\end{array}$ & $\begin{array}{l}\text { - The researcher showed the result of groups' work on the last meeting } \\
\text { and then corrected it together with the students. } \\
\text { - The students did the first post-test }\end{array}$ \\
\hline
\end{tabular}

While the researcher conducted action research in cycle $\mathrm{I}$, the observer observed the students' behavior, made field notes, took pictures, and recorded videos while the teaching and learning process was going on. These were very important to the researcher because he had to know the classroom situation during action research conducted. It was also aimed at finding out the strength and weakness of Numbered Heads Together (NHT) technique with picture series.

After doing action research and observation in cycle 2 , then the researcher analyzed the data collections like students' pre-test score, filed notes, and documentation. Based on those data, the researcher found that the students' writing score was improved, but only 19 students or $56 \%$ of 34 students who passed the minimum achievement criteria (KKM). The data also showed that some students had difficulty in using appropriate grammar when wrote a descriptive text, few groups still relied on the smartest member, some students were confused in how to make a good descriptive text, and few students were 
still nervous when they answer the result of the group's discussion.

Therefore, because the researcher still found problems in cycle 1 he decided to conduct the next cycle so that the problems would not occur anymore. The second cycle consisted of three meetings too. The topic was little different with the first cycle, it was descriptive text about tourist resorts around the world. Before conducted cycle 2, the researcher did some activities aimed to overcome the weakness in the first cycle, like revising the plan, sharing with the English teacher, making a lesson plan, and the last preparing the teaching materials, media, and tools. The summary of cycle 2 activities are described in table 3.

Table 3 Summary of Cycle 2 Activities

\begin{tabular}{|c|c|c|}
\hline Cycle & $\begin{array}{l}\text { Meeting / } \\
\text { Date }\end{array}$ & Activities \\
\hline \multirow[t]{3}{*}{ Cycle 2} & $\begin{array}{l}1^{\text {st }} \text { Meeting } \\
\text { November } 21^{\text {st }}, 2015\end{array}$ & $\begin{array}{l}\text { - The researcher decided to reduce the number of groups, to make classroom } \\
\text { control easier. } \\
\text { - The researcher distributed descriptive text with the pictures, and asked the } \\
\text { groups to do the task, consisted of understanding the word meaning, main } \\
\text { idea, detailed information, language used, and communicative purpose of } \\
\text { the text. }\end{array}$ \\
\hline & $\begin{array}{l}2^{\text {nd }} \text { Meeting } \\
\text { November } 23^{\text {rd }}, 2015\end{array}$ & $\begin{array}{l}\text { - To overcome the weakness in the first cycle, the researcher explained } \\
\text { about the aspects of good writing and the processes of good writing. } \\
\text { - The researcher decided to conduct writing activity in groups by using } \\
\text { Numbered Heads Together (NHT) technique with picture series. }\end{array}$ \\
\hline & $\begin{array}{l}3^{\text {rd }} \text { Meeting } \\
\text { November } 28^{\text {th }}, 2015\end{array}$ & $\begin{array}{l}\text { - The results of groups' work were shown on the LCD one by one, then } \\
\text { asked the other groups to give feedback orally. } \\
\text { - The students did the second post-test. }\end{array}$ \\
\hline
\end{tabular}

After did the cycle 2, then the researcher analyzed the observation findings and then presents the research findings gathered from sources of data, such as the observation report, field notes, interview, the score of pre-test and post-test, and photograph. The indicators of research findings include the improvement of the students' score, the improvement of five writing aspects, and the classroom situation. The research findings are presented in table 4.

\section{Table 4 Students' Achievement in the End of Research}

\begin{tabular}{lll}
\hline \multicolumn{2}{c}{ Indicators } & \multicolumn{1}{c}{ Research Findings } \\
\hline a. $\begin{array}{l}\text { The achievement of the } \\
\text { students' test score }\end{array}$ & $\begin{array}{l}\text { The students' mean score was improved to } 71.9 \text { in the } 1^{\text {st }} \text { post-test and } \\
\text { then improved into } 79.5 \text { in the } 2^{\text {nd }} \text { post-test. }\end{array}$ \\
\hline b. $\begin{array}{l}\text { The improvement of the } \\
\text { students' writing aspects }\end{array}$ & $\begin{array}{l}\text { After implementing Numbered Heads Together (NHT) technique, } \\
\text { students were able to write longer and more detailed descriptive text, } \\
\text { because they could share their ideas with their groups in NHT. } \\
\text { The students were able to explore their ideas because of the using picture } \\
\text { series as the teaching media helped them to explore their ideas. } \\
\text { The students' vocabulary was increased, it made their choice of words } \\
\text { not only improved but also the spelling was also correct. }\end{array}$
\end{tabular}


- After more learning and exercising the grammar use, particularly on the use of present tense, the students' mistakes were decreased.

- Most of the students wrote the correct spelling, punctuation, and capitalization.

c. The improvement of class situation
- Students pay attention to the researcher as the teacher. They felt interesting to the lesson because the researcher used appropriate teaching technique and media.

- The students gave more response when the researcher asked, they were confident to answer the question

- Students were brave to ask about their difficulty, they asked if only they really found difficulty in the process of writing and with the appropriate question.

- When Numbered Heads Together (NHT) technique was implemented, the students discussed the task with their groups.

- The students were willing to speak English in the classroom
Based on the research findings, the researcher discussed the result of the research with the relevant theories to answer the objectives of this research. First, Numbered Heads Together (NHT) technique with picture series can be implemented to teach writing. Furthermore, it can be used by the teacher as the alternative way to teach other language skill. The use of NHT technique gives many benefits to the students because most of the activities in learning activities are students' centered. According to Olsen, and Kagan (in Yeh, 2004) ) Numbered Heads Together (NHT) includes a simple four-step technique that can be utilized repeatedly with a variety of curriculum materials and can be applied to almost all subject areas, to every grade level, and to any places in a lesson. Teachers who want to conduct NHT as a teaching technique can use the following four-step structure; these are numbering, questioning, heads together or thinking together, and answering. Based on this theory, the researcher had been applied it combined with picture series as the media to teach writing descriptive text, the detailed steps can be seen in table 5 .

\section{Table 5 Steps of Conducting NHT Technique with Picture Series in Writing Class}

\begin{tabular}{|c|c|c|}
\hline No & Steps & Teaching and Learning Activities \\
\hline 1. & Numbering & $\begin{array}{l}\text { The researcher asked students to make groups. Each student had to put the number } \\
\text { heads on their heads. It had been prepared by the researcher before the teaching- } \\
\text { learning process. } \\
\text { - The purpose of wearing number heads was to know the job for each student. }\end{array}$ \\
\hline 2. & Questioning & $\begin{array}{l}\text { The researcher gave a task to the groups. } \\
\text { - The task is about writing a descriptive text based on the picture series and the } \\
\text { important information that was distributed by the researcher. }\end{array}$ \\
\hline 3. & $\begin{array}{l}\text { Heads Together / } \\
\text { Thinking Together }\end{array}$ & $\begin{array}{l}\text { - After they were given the task, each student in groups had to think together and } \\
\text { also share their ideas with their own groups. } \\
\text { The rules of NHT technique here was that the students who got number } 1 \text { and } 2 \\
\text { had to think about the first paragraph, then the students who got number } 3 \text { and } 4 \\
\text { had to think about the second paragraph, and the students who got number } 5 \text { and } 6 \\
\text { had to think about the third paragraph. }\end{array}$ \\
\hline
\end{tabular}


- Beside think together, the students also made an outline before they wrote the final version.

4.

Answering

- The groups wrote the final version of their writing.

- Besides that, all of the groups had to present their writing in front of the class. When a group was presenting their result, another group had to give opinion or comment.

Second, the use of NHT technique with picture series can get students' interest and make the classroom situation better. Related to the positive results after conducting and analyzing research in cycle 2 , the research found that there was an improvement of students' attention. When NHT technique with picture series was implemented, the students seem paid attention to the researcher's explanation, and also not busy did non-academic activity with their friends. It made the students know and understand the researcher's explanation.

In other words, there were any improvements in students' response to the researcher after the action research. This result supported by Kagan (1994: 1) that one of NHT purposes is "students are able to rehearse their responses". Moreover, it also supported by Wright (1989: 17), that pictures can motivate the students and make them want to pay attention and want to take part.

Based on the result of observation, the researcher also found that the students were more active and did not work individually when they had any difficulties. They participated to discuss the answer of the question with their own groups. This result supported by Hamm and Adams (in Flowers and Ritz, 1994: 2), By having collaboration among students, all of the students actually come to understand the material better. It has positive effects on students' self-esteem, social relations,

Third, the use of NHT technique with picture series can improve the students' writing skill. The focuses of this research involved five aspects of writing skill: developing ideas, producing text based on the generic structure, exploring their collection of words, understanding appropriate tenses and grammar in the text, the last is producing correct spelling, punctuation, and capitalization in the text.

The findings show that those aspects have higher final achievement after the research. Their ideas to make descriptive text improved, They could write longer, and they could organize their ideas into a good and correct structure, from the beginning until the ending. It proved that the using of NHT technique can explore the students' ideas. Because in NHT technique the students have to think together and also share their ideas with a group.

Furthermore, in this activity, there was transfer information in the group. For example, if the students didn't know the meaning of the words from the context of the text, he or she could ask the other friend in the group. This result supported by the theory from Flowers and Ritz (1994: 2), who stated that the using of cooperative learning as teaching technique improves the academic performance among high and low achieving students. As one of cooperative learning technique, NHT also give benefit to the students related to the result. According to Kagan (1994: 1), the purposes dealing with the use of NHT are the students are able to process information, communication, thinking, review of the material, and check prior knowledge, and then the students gain confidence in sharing their ideas. 
The use of picture series as the teaching media also improves the students' vocabulary as one of writing skill aspect. The research findings show that the students had more words to express their ideas in writing text, and also the students write with more varied vocabulary and it was correct and appropriate. This result was supported by Callahan, et al. (1992: 479) who suggest that teachers use pictures effectively because the media are very useful for the teaching. Many interpretations can be made in a picture. It can be an excellent tool and can illustrate what teachers wish to teach.

Dealing with the improvement of students' writing skill, Bell and Burnaby in (Nunan, 1998: 6), says that writing is Standard complex cognitive activity in which the writer is required to demonstrate control of content, format, sentence structure, vocabulary, punctuation, spelling, and letter formation. Beyond the sentence, the writers must be able to structure and integrate information into cohesive and coherent paragraph and text.

Related to the students' writing skill on descriptive text, the researcher concluded that there were any improvements on developing ideas, producing text based on the generic structure, exploring their collection of words, understanding appropriate tenses and grammar in the text, and producing correct spelling, punctuation, and capitalization in the text.

Besides writing aspects, the students' score in writing test also improve. From the analysis of the mean score of the writing test, it can be concluded that the use of Numbered Heads Together (NHT) Technique with picture series in writing class does improve the students' writing skill. The improvement of students' mean score could be seen in table 6 .

Table 6 the Improvement of Students' Mean Score

\begin{tabular}{ccc}
\hline $\begin{array}{c}\text { Pre-test } \\
\text { mean score }\end{array}$ & $\begin{array}{c}\text { Post-test 1 } \\
\text { mean score }\end{array}$ & $\begin{array}{c}\text { Post-test 2 } \\
\text { mean score }\end{array}$ \\
\hline 60.7 & 71.9 & 79.5 \\
\hline
\end{tabular}

\section{CONCLUSION, IMPLICATION, AND SUGGESTION}

Based on the research findings and discussion, the researcher concludes some important points. First Number Heads Together (NHT) technique with picture series can be implemented in writing class. In this research, the researcher tried to combine Numbered Heads Together (NHT) as the teaching technique with picture series as the teaching media to teach writing.

There are four main steps that have to follow the teacher when conducting NHT Technique, these are numbering, questioning, heads together or thinking together, and answering. When teaching writing by NHT technique, the researcher provides picture series as the teaching media. Even there are several media that can be used; the researcher thinks that picture series is the effective media to teach writing.

Second, the use of Number Heads Together (NHT) technique with picture series gives good impact in the class situation. It is able to make students not to be noisy during English teaching-learning process in the classroom. The atmosphere of the class became more alive, enjoyable and 
fun. The teaching-learning process also ran smooth and effective because they become respect. From the interview and observation result, the researcher also found that the use of picture series as the teaching media makes the students not bored and free from monotonous activity during the lesson. They said that picture series are interesting media that can help them to have higher motivation and interest in joining writing class.

The last conclusion is the use of Numbered Heads Together (NHT) Technique with picture series in teachinglearning of descriptive text is able to improve the students' writing skills that cover developing ideas, producing text based on the generic structure, exploring their collection of words, understanding appropriate tenses and grammar, and producing correct spelling, punctuation, and capitalization. The improvement of the students' writing skill a by the result of the test scores. The mean score of pre-test was 60.7, and it improved to 71.9 in post-test 1 and it also improved to 79.5 in post-test 2 . It proved that the use of Numbered Heads Together (NHT) Technique with picture series in teaching writing can improve students' writing skill.

There are several implications that are relevant to the teaching English. It can be found from the conclusion drawn from the research finding and discussion. The result of the research showed that the use of NHT technique with pictures as the teaching media brings improvements in students' writing skills and the classroom situation. Besides that, it helped the teacher to deliver materials for students. It also helped the students to learn English easily. In conclusion, the researcher recommended teachers to use NHT technique with pictures as the teaching media as one of alternatives way to teach writing.
After the discussion, the researcher would like to give some suggestion for English teacher, students, and other researchers. The suggestions are as follows: (1) English teachers should improve their creativity in teaching English. They should choose an appropriate technique and media to be implemented in the class. If they want to implement Numbered Heads Together (NHT) technique with picture series, they should give a clear and complete instruction.

(2) For students, they should motivate themselves to learn English; they must pay full attention to their teacher when their teacher is explaining materials, and they have to learn English continually not only at the school but also at home in order to upgrade their achievement in English lesson.

(3) To other researcher, are expected to use the finding of this research as a foothold to conduct other research by using Numbered Heads Together (NHT) Technique with picture series to other language skills such speaking, reading, listening even vocabulary mastery.

\section{BIBLIOGRAPHY}

Anitah, Sri. 2008. Media Pembelajaran. Surakarta: LPP UNS \& UNS Press.

Brown, H. Douglas. 2001. Teaching by Principles: An Interactive Approach to Language Pedagogy. Second Edition. San Fransisco: Longman.

Burns, Anne. 1999. Collaborative Action Research for English Language Teachers. Cambridge: Cambridge University Press.

Cooper, P. and McIntyre, D.1996. Effective Teaching and Learning: Teachers' and Students' Perspective. Philadelphia: Open University Press. 
Hamm, Mary \& Dennis, Adams. 1994. The

Collaborative Dimensions of Learning. Norwood, NJ: Ablex Publishing Company.

Hopkins, David. 1993. A teachers Guide to Classroom Research. Buckingham: Open University Press.

Kagan, S. 1994. Cooperative Learning. San Juan Capistrano, CA: Resource for Teacher Inc.

Kementerian Pendidikan dan Kebudayaan. 2013 Kurikulum 2013: Kompeteensi Inti dan Kompetensi Dasar Mata Pelajaran Bahasa Inggris Sekolah Menengah Atas dan Madrasah Aloyah. Jakarta: Kementerian Pendidikan dan Kebudayaan.

Kemmis, Stephen. \& Mc Taggart, Robin. 1990. The Action Research Planner. Australia: Deakin University.

Lie, Anita. 2004. Cooperative Learning. Jakarta: Grasindo.

Nunan, David. 1998. Language Teaching Methodology. United Kingdom: Prentice Hall International (UK) Ltd.

Scott, W. A. \& Ytreberg, L.H., 1990. Teaching English to Children. New York: Longman.

Westwood, Peter. 2008. What Teachers Need to Know about Learning Difficulties. Victoria: ACER Press. 